\title{
Clinical features of the patients with recurrent massive pericardial effusion: single center experience
}

\section{Tekrarlayan masif perikardiyal efüzyonlu hastaların klinik özellikleri: Tek merkez deneyimi}

\author{
Fatilh Ada ${ }^{1}$, Sadık Volkan Emren²
}

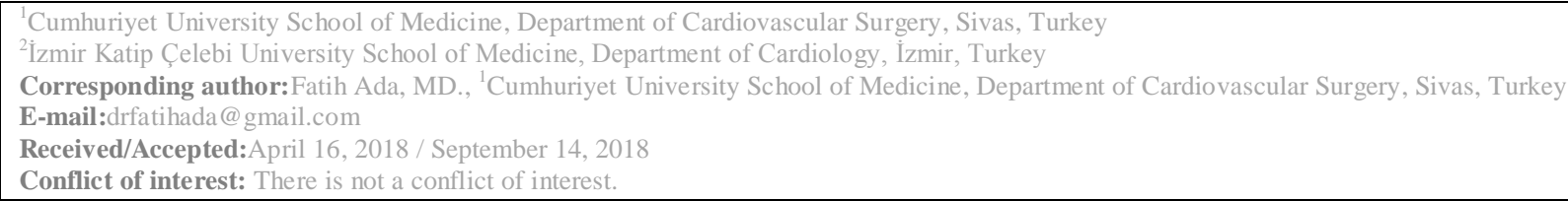

\section{SUMMARY}

Objective: In this study, we aimed to determine the clinical features of patients with recurrent pericardial effusion. We also aimed to evaluate the clinical course and the outcomes of the patients with recurrent pericardial effusion who underwent percutaneous and surgical interventions.

Method: 22 patients with recurrent massive pericardial effusion were retrospectively evaluated. We recorded the primary etiologies of effusion, laboratory parameters, and time of the recurrence of effusion, type of the pericardial drainage and also one year mortality of the patients after pericardial drainage.

Results: Mean age of the patients was $60 \pm 16$ and $64 \%$ were male. The most common cause was malignancy (31\%) followed by idiopathic (27\%), postcardiotomy syndrome (13,5\%), renal failure(13,5\%), autoimmune disease (10\%), and heart failure (5\%). Median recurrent time was 46 days (interquartile range 16-78 days). The characteristics of the pericardial fluid at initial intervention consist of 59.5\% serohaemorrhagic, $27 \%$ serous and 13,5\% hemorrhagic pericardial effusion . Majority of patients (73\%) underwent subxiphoid tube drainage and the remaining patients (27\%) underwent percutaneous pericardiocentesis in first intervention. 9 (40.9\%) patients died in one year follow up. Of the dead patients, $55.5 \%$ had malignity, $22.2 \%$ had postcardiotomy syndrome and $22.2 \%$ had renal failure.

Conclusions: The most common cause of death and recurrent pericardial effusion was malignancy. Idiopathic recurrent pericarditis, autoimmune disease and congestive heart failure are the most benign pathology in which the patients had no mortality in a 1 year follow up period.

Keywords: Pericardial Effusion, Chronic Renal Failure, Cardiac Surgery, Malignancy 
Yöntem: Tekrarlayan masif perikardiyal efüzyonu olan 22 hasta retrospektif olarak değerlendirildi. Efüzyonun; primer etiyolojisi, laboratuvar parametreleri, efüzyon tekrarını, perikardiyal drenajın şekli ve ayrıca perikardiyal drenaj sonrası hastaların bir yıllık mortaliteleri değerlendirildi.

Bulgular: Hastaların yaş ortalaması $60 \pm 16$ ve\% 64 'ü erkekti. En sık görülen tekrarlayan efüzyon nedeni malignite idi (\% 31), ardından sırasiyla idiyopatik (\% 27), postkardiyotomi sendromu (\% 13.5), böbrek yetmezliği ( $\%$ 13.5), otoimmün hastalık (\% 10) ve kalp yetmezliği (\% 5) geliyordu. Ortalama tekrarlama süresi 46 gündü (minimummaksimum aralık 16-78 gün). Perikardiyal sıvının başlangıçtaki özelliklerine bakıllı̆̆ında \% 59.5 serohemorajik, \% 27 seröz ve\% 13.5 hemorajik efüzyondan oluşmaktaydı. İlk girişim şekli olarak hastaların büyük çoğunluğuna (\% 73) subksifoid drenaj uygulandı ve kalan hastalara (\% 27) perkütan perikardiyosentez yapıldı. Bir yıl içinde 9 (\% 40.9) hasta kaybedildi. Kaybedilen hastaların\% 55.5'inde malignite, \% 22.2'sinde postkardiyotomi sendromu ve\% 22.2'sinde böbrek yetmezliği vardı.

Sonuç: En sık ölüm ve tekrarlayan perikardiyal efüzyon nedeni malignite idi. İdiyopatik rekürren perikardit, otoimmün hastalık ve konjestif kalp yetmezliği, hastaların 1 yıllık takip döneminde mortalitesi olmayan en benign patolojilerdi.

Anahtar sözcükler: Perikardiyal Efüzyon, kronik böbrek yetmezliği, kalp cerrahisi, malignite

\section{INTRODUCTION}

Pericardial effusion is a common finding in clinical practice occurring either as an incidentally or a manifestation of a systemic or cardiac disease. Unfortunately, there are few data regarding the clinical and prognostic features of recurrent effusions in the clinical setting.

It is unclear whether percutaneous or surgical treatment strategies should be changed based on etiology in patients with massive pericardial effusion. However currently appropriate treatment and diagnosis should include complete and permanent drainage, and adequate histological, cytological and microbiological material. In addition, the applied method should have minimal mortality and morbidity rates ${ }^{1}$.

According to 2015 European Society of Cardiology (ESC) pericardial diseases guideline; urgent pericardiocentesis is recommended if the etiology score, clinical presentation score and the imaging method score is over 6 , while follow-up is recommended if the score is below $6^{2}$.

The first known pericardial drainage operation was performed by Larrey ${ }^{3}$.Since then, many techniques have been developed. However, subxiphoid pericardial drainage currently the most popular technique for massive pericardial effusion. Nowadays, with the development of imaging modalities, percutaneous drainage is performed excessively with echocardiography. However, surgery is unavoidable in some cases such as frequent recurrences and adhesions. In fact, occasional pericardial pleural window operations are mandatory.
In this study we evaluated the clinical features and mortality rate of the patients who undergone percutaneous or surgical pericardial drainage due to recurrent massive pericardial effusion.

\section{MATERIAL AND METHODS}

In this study, we retrospectively evaluated 22 patients with recurrent massive pericardial effusion causing tamponad, admitted to Afyonkarahisar state hospital between 2001-2016. Patients were treated with interventional methods including percutaneous or surgical drainage. Besides, patients were investigated in terms of age, sex, etiology, laboratory values, quality and quantity of drainage fluid, drainage method, time of the recurrences-duration, and mortality parameters.

All surgical subxiphoid pericardiostomies were performed under local anesthesia and sedation. None of the cases required general anesthesia. After the incision was made about $3 \mathrm{~cm}$ below and above the xiphoid process, xiphoid was cut with a scissors. When the pericardium was visualized, $2 \mathrm{~cm}$ incision was performed with the appropriate surgical instruments. In addition, pericardial biopsies with cytologic and microbiological samples were taken from pericardial fluid. A 32 fr tube was placed into the mediastinum after the procedure. The tube wasn't removed until the pericardial drainage stop. The drain was removed approximately at fourth day after the procedure. Sclerosing agents such as pericardial powder or tetracycline were not 
administrated. There was no mortality during surgery.

Percutaneous drainage was chosen for patients with unstable hemodynamic status and for those who were unsuitable for open surgery. Also, percutaneous drainage was performed under the local anesthesia with sterile conditions. All interventions were performed with transthoracic echocardiography. At first a 18 gauge introducer needle was inserted to pericardium then agitated saline injected to the pericardium to confirm to localization of needle. Then a $12 \mathrm{fr}$ Double lumen dialysis catheter was placed in mediastinum with a guide wire. Haemovac drains were connected to the ends of both catheters. Cytological and microbiological samples were taken from drainage fluid. However, pericardial biopsy wasn't performed to these patients.

\section{Statistical Analysis:}

Statistical analyses were performed with SPSS 24 package statistical program (StataCorp LP, College Station, TX, USA continuous variables were expressed as mean \pm standard deviation (SD) and categorical variables were expressed as frequency and percentage (\%).

\section{RESULTS}

We evaluated 22 patients with recurrent pericardial effusion. The mean age of the patients was $60 \pm 16$ and $64 \%$ were male (Table 1). The etiology of the pericardial effusion consists of $31 \%$ malignancy, $27 \%$ idiopathic, $13,5 \%$ chronic renal failure, $13,5 \%$ postcardiotomy syndrome, $10 \%$ autoimmune disease, and 5\% congestive heart failure. 9(40.9\%) patients died in one year follow up. Of the dead patients $55,5 \%$ had malignity, $22,2 \%$ had postcardiotomy syndrome and $22,2 \%$ had renal failure (Table 2).On the laboratory parameters, creatinine was minimally high (1.29 mg / dL) and calcium (8,06 mg / dL), albumin $(3,29 \mathrm{mg} / \mathrm{dL})$ and total protein $(6,20 \mathrm{mg}$ / dL) were minimally low. Lactate dehydrogenase (LDH) (504,76 U / L) was very high. There were no distinctive differences in other laboratory values (Table 3 ). Of the first interventions, $73 \%$ were percutaneous drainage, while the remaining $27 \%$ were surgical drainage. In the second interventions, the rate of surgical and percutaneous methods was $86.5 \%$ and $13.5 \%$ respectively. In first intervention, mean drained fluid volume was $668.75 \mathrm{ml}$ in subxiphoid and $483.3 \mathrm{ml}$ in percutaneous drainage. In the second intervention, mean drained fluid volume of subxiphoid and percutaneous drainage was $621.05 \mathrm{ml}$ and $505.6 \mathrm{ml}$ respectively (Table 4).The characteristics of pericardial fluid in first drainages include $59.5 \%$ serohemorrhagic, $27 \%$ serous and $13.5 \%$ hemorrhagic and those in second intervention include $68.1 \%$ serohemorrhagic, $22.7 \%$ serous and $9.2 \%$ hemorrhagic (Table 5). Median duration of recurrence was 46 days (interquartile range 16-78 days).

Table 1: Demographic data of the patients

\begin{tabular}{|l|l|l|}
\hline Variable & $n$ or $\bar{x}+$ sd & $\%$ or min-max \\
\hline Age $($ years $)$ & $60 \pm 16.02$ & $23-90$ \\
\hline Male $(\mathrm{n})$ & 14 & 64 \\
\hline Female $(\mathrm{n})$ & 8 & 36 \\
\hline Smoking $(\mathrm{n})$ & 4 & 18 \\
\hline Diabetes $(\mathrm{n})$ & 12 & 54 \\
\hline Hypertension $(\mathrm{n})$ & 14 & 64 \\
\hline
\end{tabular}


Table 2: Etiology of the recurrent pericardial effusion

\begin{tabular}{|l|l|l|}
\hline Etiology & $\mathrm{n}(22), \%(100)$ & Mortality in one year (n, \% ) \\
\hline Malignancy (n) & $7(31 \%)$ & $5(71,5 \%)$ \\
\hline İdiopatic (n) & $6(27 \%)$ & $0(0 \%)$ \\
\hline Chronic renal failure (n) & $3(13,5 \%)$ & $2(66,6 \%)$ \\
\hline Postcardiotomy syndrome (n) & $3(13,5 \%)$ & $2(66,6 \%)$ \\
\hline Otoimmun disease (n) & $2(10 \%)$ & $0(0 \%)$ \\
\hline Congestive heart failure (n) & $1(5 \%)$ & $0(0 \%)$ \\
\hline
\end{tabular}

Table 3: Laboratory data of the patients

\begin{tabular}{|l|l|l|}
\hline Laboratory data & $\overline{\mathrm{x}}+\mathrm{sd}$ & Normal range \\
\hline $\begin{array}{l}\text { Blood Urea Nitrogen }(\mathrm{BUN}) \\
(\mathrm{mg} / \mathrm{dL})\end{array}$ & 29,7 & $6.5-33$ \\
\hline Creatinine $(\mathrm{mg} / \mathrm{dL})$ & 1,29 & $0.56-1.2$ \\
\hline Glucose $(\mathrm{mg} / \mathrm{dL})$ & 98,4 & - \\
\hline Sodium $(\mathrm{mEq} / \mathrm{L})$ & 137 & $136-146$ \\
\hline Potassium $(\mathrm{mEq} / \mathrm{L})$ & 4,26 & $3.5-5.1$ \\
\hline Calcium $(\mathrm{mg} / \mathrm{dL})$ & 8,06 & $8.8-10.6$ \\
\hline Corrected Calcium $(\mathrm{mg} / \mathrm{dL})$ & 8,54 & - \\
\hline Albumin $(\mathrm{g} / \mathrm{dL})$ & 3,29 & $3.5-5.3$ \\
\hline Protein $(\mathrm{g} / \mathrm{dL})$ & 6,20 & $6.6-8.3$ \\
\hline $\begin{array}{l}\text { Lactate Dehydrogenase }(\mathrm{LDH}) \\
(\mathrm{U} / \mathrm{L})\end{array}$ & 504,76 & $<247$ \\
\hline Hemoglobin $(\mathrm{g} / \mathrm{dL})$ & 11,69 & $14-18$ \\
\hline $\begin{array}{l}\text { White Blood Cell }\left(\mathrm{WBC} \times 10^{9}\right. \\
/ \mu 1)\end{array}$ & 8,24 & $4-11$ \\
\hline
\end{tabular}

Table 4: Intervention types of the recurrent pericardial effusion

\begin{tabular}{|l|l|l|}
\hline & Subxiphoid drainage (\%) & Percutan drainage (\%) \\
\hline First intervetion (n) & $16(73 \%)$ & $6(27 \%)$ \\
\hline Second intervention (n) & $19(86,5 \%)$ & $3(13,5 \%)$ \\
\hline $\begin{array}{l}\text { First drainage mean volume } \\
(\mathrm{ml})\end{array}$ & 668,75 & 483,3 \\
\hline $\begin{array}{l}\text { Second drainage mean volume } \\
(\mathrm{ml})\end{array}$ & 621,05 & 505,6 \\
\hline
\end{tabular}

Table 5: Fluid types of the recurrent pericardial effusion

\begin{tabular}{|l|l|l|}
\hline & First drainage fluid type (\%) & Second drainage fluid type (\%) \\
\hline Serous (n) & $6(27 \%)$ & $5(22,7 \%)$ \\
\hline Serohemorrhagic (n) & $13(59,5 \%)$ & $15(68,1 \%)$ \\
\hline Hemorrhagic (n) & $3(13,5)$ & $2(9,2 \%)$ \\
\hline
\end{tabular}




\section{DISCUSSION}

To our best knowledge, there is few publication about recurrent pericardial effusions. Most of the publications relate to pericardial effusion include drainage techniques. In a study by Allen et al. mortality rate of subxiphoid drainage was $0.6 \%$, complication rate was $1.5 \%$ and recurrence rate was $3.5 \%$ in patients with pericardial effusion. In the same study, the rate of percutaneous drainage was e similar to the subxiphoid drainage ${ }^{1}$.

In a study of Dosios et al., etiologies of effusions consist $46 \%$ malignancy, 27\% idiopathic, $12 \%$ chronic renal diseases, $12 \%$ infectious diseases, $3 \%$ connective tissue disease, $2 \%$ cardiac surgery, $1 \%$ cardiomyopathy, $1 \%$ radiotherapy. 1-year mortality was $93.1 \%$ in malignancy-derived effusions ${ }^{4}$. In our study, 1-year mortality of recurrent malignancy was $71.5 \%$.

Without these known factors, there are rarely observed factors that cause recurrent effusion. One of these factors is surgically treated case of pellet injury that caused recurrent effusion in a 12 year old girl ${ }^{5}$.

In a study of Altıntaş et al, Subxiphoid drainage and drainage with lateral thoracotomy technique were compared and there was no significant differences regarding mortality and mobility between both techniques. In our study, surgical drainage was performed by subxiphoid to all patients.

In a study of Yüksel et al., uremic pericarditis was the most common etiology, followed by malignancy and idiopathic effusions. Subxiphoid drainage was observed to be safe and effective in the treatment of patients with pericardial effusion 7. However, this study included only patients who had undergone first drainage. The higher rate of malignancy in our study can be explained by the higher recurrence rate.

Various techniques had been tried for the treatment of pericardial effusion other than surgical treatment and percutaneous drainage. Pericardial talc, tetracycline and cisplatin are some of these treatment choices. Pericardial cisplatin is applied especially in malignancy related effusions ${ }^{8}$. In the treatment of effusion related with malignancy, thiotepa, bleomycin, mitoycin, mitoxantrone, radioactive chromic phosphate and OK-432 were also applied instead of cisplatin in the treatment of malignancy related effusions.

\section{CONCLUSION}

Mortality rate is higher in patients with recurrent effusion related to malignancy, regardless of treatment strategies or features. Recurrent effusions related to idiopathic, autoimmune diseases and congestive heart diseases are more benign etiologies in terms of mortality.

\section{REFERENCES}

1. Allen KB, Faber LP, Warren WH, et al. Pericardial effusion: subxiphoid pericardiostomy versus percutaneous catheter drainage. Ann Thorac Surg 1999;67:437-40.

2. Adler Y, Charron P, Imazio M, et al. 2015 ESC Guidelines for the diagnosis and management of pericardial diseases: the Task Force for the Diagnosis and Management of Pericardial Diseases of the European Society of Cardiology (ESC). Endorsed by: the European Association for Cardio-Thoracic Surgery (EACTS). Eur Heart J 2015;36:2921-64.

3. Larrey EL. New surgical procedure to open the pericardium in the case of fluid in the cavity. Clin Chir 1829;36:303-37.

4. Dosios T, Theakos N, Angouras D, et al. Risk factors affecting the survival of patients with pericardial effusion submitted to subxiphoid pericardiostomy. Chest 2003;124:242-246.

5.Tutar HE, Atalay S, Uysalel A, et al. Recurrent pericardial effusion due to gunshot wound of the heart in a hemodynamically stable child-a case report. Angiology 1999; 50: 337-40.

6.Altintas G, Yasar E, Kadirogullari E, et al. A comparison of two surgical techniques for symptomatic pericardial effusion after cardiac surgery: subxiphoid open pericardial drainage and lateral thoracotomy. Turk Gogus Kalp Dama 2014;22(1):29-34.

7. Yüksel V, Hüseyin $\mathrm{S}$, Okyay $\mathrm{A}$, et al. Erişkinlerde subksifoidal perikardiyostomi yöntemi ile perikardiyal efüzyon tedavisi. Turk Gogus Kalp Dama 2012;20(3):492-496

8.Maisch B, Ristic' AD, Pankuweit S, et al. Neoplastic pericardial effusion: efficacy and safety of intrapericardial treatment with cisplatin. Eur Heart J 2002;23:1625-31. 